\title{
Tire Purchasing: Does it Have a Place Online?
}

Joshua Thomas Aarbo, Kennedy Anderson, Marco F. Bruni, Julia Liosis \&

Madison Lang

\section{Abstract}

This article outlines our collaboration with Tireland, in which we conducted research regarding the potential success of selling tires online. We looked into aspects of an online presence that would be positively received by consumers in the tire industry. Our research has included an interview with the decision maker, five in-depth interviews, and an online questionnaire. The aim of these methods was to gain a further understanding of the current online tire industry and the constraints that may be present when implementing an ecommerce sales strategy. The target market we focused on includes males and females between the ages of twenty to thirty. We received 114 responses to our online survey, of which 103 were part of our target market. The data we aimed to collect helped us compare variables such as level of education, online features, and annual household income, with the individual's likelihood to purchase tires online. It is through our SPSS analysis that we were able to gather a better understanding on the statistics surrounding the problem at hand.

Our studies offered an insight into the necessary elements required to create a successful ecommerce platform. Based on our five research questions, we determined that while variables such as income and education have a minor impact on the likelihood to purchase tires online, other variables such as the availability of online features, tire characteristics, and the history of online shopping, are significant. Our analyses have led us to recommend that the company should target individuals who already typically shop online. As well,

Vol. 4(1) | DOI: https://doi.org/10.31542.muse.v4i1.863 MacEwan University Student eJournal

(C) 2020 under CC BY-NC I ISSN 2369-5617 


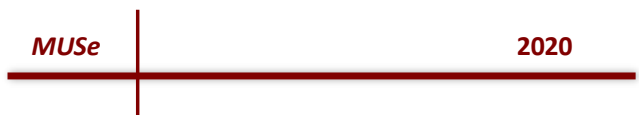

characteristics such as availability, customer service, and price are important to consumers when making a purchase. Finally, consumers are more willing to shop on a website that offers reviews, product information, reminders, and an online question service. Focusing upon these variables will be the greatest way for a company to implement a successful ecommerce platform.

Keywords: Tire Purchasing, Website Features, Incentives for Online Purchasing, Access to Information Online, Customer Preferences, Marketing Research

\section{Problem Definition}

Tireland specializes in tire sales throughout retail outlets across Canada and is looking into implementing an ecommerce sales strategy into their business. However, while ecommerce is a well-established form of sales in other industries, the tire industry is currently somewhat limited to in-person sales due to the nature of tire purchasing. Throughout our research we have examined the potential to adapt an ecommerce platform to fit the tire industry.

In order to define the management and marketing research problems, we conducted various forms of exploratory research. First, we collected and analyzed twenty-five scholarly articles to conduct a literature review. From this we were able to gain a foundation for our interview with Tireland's Marketing Manager, where we obtained valuable insights into the management problem and other key information for defining the marketing research problem. After the interview, we conducted five in-depth interviews where we were able to gain an understanding of the nature of the target market in regard to purchasing tires online. After conducting these various methods of exploratory research, we were better able 
to understand how tires can be successfully sold on an ecommerce platform.

Our next focus was on defining the marketing research problem, where we were able to use the interviews to assist us through the coding process. Following the process of coding, categorizing, and theming, we were able to establish four themes: availability of information, preferred website features, accessibility to acquiring tires, and incentives for online purchases. After conducting exploratory research, we were able to define the marketing research problem into three main questions:

1. What online tools are necessary to encourage customers to purchase tires online?

2. What are the most important factors when purchasing tires online?

3. What obstacles need to be overcome to enable individuals to purchase tires online?

These questions provide necessary insight for resolving the management problem and establishing a guideline to focus on when conducting further research.

\section{Analytical Framework of the Marketing Research Problem}

\section{Analytical Model}

After an initial interview with Tireland's Marketing Intelligence Officer, we chose to focus our research on discovering what, if anything, would encourage consumers aged 20 to 30 to buy tires online. In order to gain more knowledge on the issue, we conducted exploratory research. The first step we included was the collection, synthesis and analysis of 25 articles related to the issue. This research led to some main topics that we believed would be a solid basis for furthering our research: online consumer buying behaviour, online presence, competitive advantage, product costs and stocking, and customer expectations.

Our second step was conducting in-depth interviews with five individuals from our target market. We used the target 


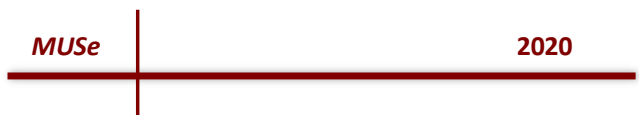

market that had been outlined by Tireland's Marketing Manager, which is defined as men and women between the ages of 20 to 30 who own a vehicle. We then created an outline consisting of ten questions to guide in-depth interviews; this discussion guide is available in Appendix B. We gained knowledge based on detailed responses, which were then coded. This resulted in the identification of four main themes:

- Availability of Information

- Preferred Website Features

- Easy Access to Acquire Tires

- Incentives for Online Purchase

These themes influenced the questions we created for our questionnaire, which can be found in Appendix A. We focused on asking questions that related to these four themes and could be used to answer our marketing research questions. More specifically, the issues we focused on are presented in the analytical framework model in Fig. 1. We then conducted the questionnaire and received 103 responses within our target market, which were analyzed and used as a basis for determining the recommendation we presented to Tireland.

Fig. 1: Analytical Framework Model for How Can We Attract 20 to 30 Year Olds to Shop Online for Tires?

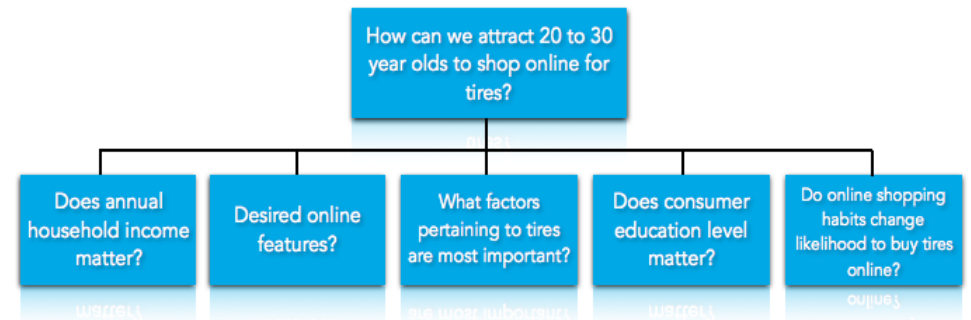

Research Questions and Hypotheses

During the stage of creating our survey, there were five research questions we wanted to answer by collecting quantifiable data. These questions are listed below: 
- Does the annual household income of respondents in our target market affect the likelihood that they will purchase tires online?

- What will be the most important factors to the consumer when online tire shopping?

- Will having unique website features help encourage consumers to purchase tires online?

- Will education influence which factors are the most important when purchasing tires?

- Is there a correlation between the likelihood that respondents would shop online and how likely respondents would purchase tires online?

By creating these five research questions, we were able to tailor our survey questions to ensure our survey data would provide an answer for each. The questions we asked were based on themes that seemed prevalent and important based on previous secondary and qualitative research, but that we thought could benefit from further exploration. We also created a hypothesis for each question. Through the analysis of our survey data, we were able to conclude the accuracy of our hypotheses. Each question is listed below, along with it's corresponding hypothesis.

Research Question \#1: Does the annual household income of respondents in our target market affect the likelihood that they will purchase tires online?

Hypothesis: Yes. We believe annual household income will influence the likelihood to purchase tires online. This belief is due to the fact that in most cases, those with a high annual household income have a larger amount of discretionary income. According to a study by Nah-Hua and Ya-Wen, recreation is a more common reason for online shopping than convenience is (2015). Due to having a higher discretionary income, it is our prediction that those with high incomes will be more familiar with recreational online shopping. Therefore, 


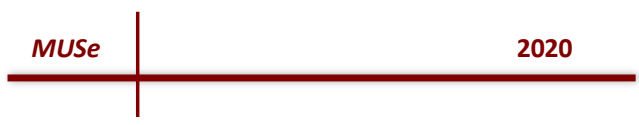

we believe they will be more comfortable with and willing to shop for tires online.

Research Question \#2: What will be the most important factors to the consumer when online tire shopping?

Hypothesis: Based on the qualitative research, we believe that price, customer service, and brand will be a common factor favoured among our participants. Our quantitative research should prove this to be correct. This is also derived from Jing and Lewis's study of the dependency of a website to accurately and consistently explain pricing, stock availability and product information to the consumer (2011). However, we want to see if these factors alter the likelihood to purchase tires online, which we do believe will alter their decision.

Research Question \#3: Will having unique website features help encourage consumers to purchase tires online?

Hypothesis: Yes. The in-depth interviews we performed proved that most individuals were more willing to purchase online if they could receive a level of service they may not find in store. Our research established "customer reviews and ease of price comparisons as the reasons why more than half purchase personal electronics online" (Sikora, 2014). Therefore, if the tire website could offer features which would enhance the shopping experience, we believe consumers would be more willing to purchase tires online. We predict that all of the online features we have selected will positively influence the consumer to purchase tires online.

Research Question \#4: Will education influence which factors are the most important when purchasing tires?

Hypothesis: Yes. Although not always the case, the consensus is that the higher the education you've received, the more knowledge you must have. With that said, it's expected that the younger the individual and the less educated they are, the less importance they will place on brand and company and the 
more importance they will place on price. In contrast, it is expected that higher educated individuals will place more importance on availability of tires and travel distance. Having said that, these individuals will likely have less time reserved to wait for tires to be available or, additionally, will have less opportunity to drive long distances to purchase the perfect tires. "Internet is the fastest-growing medium so far; and as such, it has become an inescapable reality which companies and individuals need to accept and learn how to implement" (Bulearca \& Bulearca, 2009). This was affirmed from our indepth interviews and considering, for the most part, higher educated individuals have more job opportunities, learning how to use the Internet is a valuable tool for the present and future.

Research Question \#5: Is there a correlation between the likelihood that respondents would shop online and how likely respondents would purchase tires online?

Hypothesis: Yes, it is expected that there is a correlation between the two variables. Tireland is looking to target an online demographic between the ages of 20 to 30 . Our literature shows that this demographic is favourable as it falls into a category of younger consumers who are more likely to purchase online "due to their level of internet usage experience" (Akar \& Nasir, 2015). Because those who would buy online are comfortable with how it works and any potential risks associated with online purchases, they would likely be less apprehensive when choosing to purchase tires online. Therefore, it is expected that the individuals who would choose to shop online are also likely to purchase tires online.

\section{Research Design}

\section{Data Collection}

After hearing Tireland's purpose for doing research, we knew we were interested in finding more information on the topic of online tire buying. We initiated our research by conducting five 
in-depth interviews on both male and female individuals that fit Tireland's target market of 20 to 30-year-old consumers. Upon completion of these interviews, a detailed questionnaire was created to find more information on online tire purchasing through additional people. In total, 114 people completed the online survey, however, only 103 people were included in the analyses as the additional 11 people were outside the target market. Though we planned to have both in-person and online surveys, we only required an anonymous online survey, done through Google Forms, to reach our survey quota and to gain enough data to analyze. This survey was posted on the Facebook pages of each member of our group, which allowed us to garner the information we needed in four days. Although the individuals who completed our survey were completely random, we were able to gather information that was fairly equal in distribution between males and females. Additionally, our target market encompassed more than $90 \%$ of the respondents. Table 1 below shows the demographic information for the 103 respondents in our target market of consumers ranging in age from 20 to 30 -years-old. 
Table 1: Demographic Information for Survey Respondents

\begin{tabular}{|c|c|c|}
\hline Variable & \# of Respondents & $\%$ of Respondents \\
\hline $\begin{array}{l}\text { Age } \\
20-30\end{array}$ & 103 & $90.4 \%$ \\
\hline $\begin{array}{l}\text { Gender } \\
\text { Male } \\
\text { Female } \\
\text { Other }\end{array}$ & $\begin{array}{c}44 \\
57 \\
2\end{array}$ & $\begin{array}{c}42.7 \% \\
55.3 \% \\
1.9 \%\end{array}$ \\
\hline $\begin{array}{l}\text { Level of Education } \\
\text { High School } \\
\text { Diploma } \\
\text { Degree } \\
\text { Masters } \\
\text { PHD } \\
\text { Other }\end{array}$ & $\begin{array}{c}44 \\
24 \\
29 \\
1 \\
1 \\
4\end{array}$ & $\begin{array}{c}42.7 \% \\
23.3 \% \\
28.2 \% \\
1.0 \% \\
1.0 \% \\
3.9 \%\end{array}$ \\
\hline $\begin{array}{l}\text { Annual Household Income } \\
\$ 20,000 \text { or Less } \\
\$ 20,001-40,000 \\
\$ 40,001-60,000 \\
\$ 60,001-80,000 \\
\$ 80,001-100,000 \\
\$ 100,000+ \\
\text { Prefer Not to Say }\end{array}$ & $\begin{array}{c}31 \\
25 \\
9 \\
4 \\
2 \\
19 \\
13\end{array}$ & $\begin{array}{c}30.1 \% \\
24.3 \% \\
8.7 \% \\
3.9 \% \\
1.9 \% \\
18.4 \% \\
12.6 \%\end{array}$ \\
\hline $\begin{array}{l}\text { Hours Worked per Week } \\
\text { None } \\
5-10 \\
10-20 \\
20-30 \\
30-40 \\
40+\end{array}$ & $\begin{array}{l}25 \\
14 \\
24 \\
12 \\
14 \\
14\end{array}$ & $\begin{array}{l}24.3 \% \\
13.6 \% \\
23.3 \% \\
11.7 \% \\
13.6 \% \\
13.6 \%\end{array}$ \\
\hline
\end{tabular}

Development, Pre-Test, and Execution of the Questionnaire In order to formulate our questionnaire, we first had to gather additional information only available through Tireland, specifically regarding what they were hoping to obtain from our research. We expanded our knowledge of Tireland through 


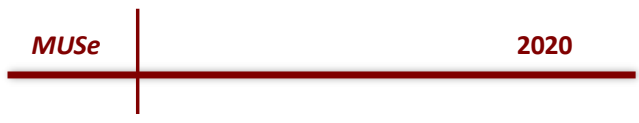

an over-the-phone conversation with a Tireland representative. Valuable information from the conversation included the target market they were hoping to attract with online sales, as well as the goal of understanding whether online tire sales could be plausible in the tire industry as a whole. After gathering an adequate amount of information using this method, we turned to online articles, followed by five in-depth interviews, to analyze and understand the data further. All of this considered, we were able to establish a questionnaire that would develop results specific to whether online tire purchasing could be beneficial to the tire industry, or not. It only took four days to gather 114 responses, which generated enough information for an analysis. Furthermore, once all these responses were gathered from Google Forms, we were able to create an Excel file and an SPSS file, which were crucial to our final analysis.

\section{Ethical Issues}

Since all our researchers have completed the Tri-council Policy Statement 2, we knew there were some ethical issues that we must consider. Considering our research was conducted solely online, we were exposed to a limited number of ethical issues. Prior to taking the survey, respondents were given the opportunity to observe a consent form. This consent form provided them with specific information such as the purpose of the survey. In addition, the form stated that respondents only had to answer questions they were comfortable with. As well, they could withdraw from taking the survey at any time and for any reason. Furthermore, the MacEwan University Ethics Board approved our project on ethical grounds. We can guarantee that the collected data was stored on the computer of a principle investigator and when the data is no longer required, will be destroyed. Bearing in mind that we shared our survey as a public document on a massive social media site, Facebook, we did compromise our survey to a certain level. In order to obtain a higher response rate, it made sense to use this 
strategy, however, by reaching a broader spectrum of individuals in the way we did, we cannot be completely confident that the individual participants valued the importance of the results to the level we expected.

\section{Data Analysis and Results}

In order to analyze our research questions, we conducted a bivariate analysis. Using these methods, we were able to find answers to our five questions and determine if expected relationships between variables existed. A bivariate analysis was used to determine a relationship between five variables and the likelihood to purchase tires online. Annual household income, important factors, education, and the likelihood to shop online were all compared against the likelihood to purchase tires online. We also used univariate analysis to gain a better understanding of responses for individual variables.

\section{Univariate Analysis of Key Variables}

In order to better understand the key variables from our analytical model, we have conducted a univariate analysis for each. Tables 2 through 5 illustrate the results of the univariate analyses. Some key takeaways that our analysis showed include that, when their preferred website features were available, 43.7 percent of respondents would be likely to purchase tires online. Price was evidently the most important factor to respondents when considering buying tires. The website feature that respondents said they were most likely to use is reviews. In terms of shopping online in general, $45.6 \%$ of respondents said they are likely to shop online. 
Table 2: Descriptive Statistics for Likelihood That You Would Shop Online

\begin{tabular}{|l|r|r|}
\hline & Frequency & \multicolumn{2}{|c|}{ Percent } \\
\hline Very Unlikely & 6 & $5.8 \%$ \\
\hline Neutral & 19 & $18.4 \%$ \\
\hline Unlikely & 8 & $7.8 \%$ \\
\hline Likely & 47 & $45.6 \%$ \\
\hline Very Likely & 23 & $22.3 \%$ \\
\hline Total & 103 & $100.0 \%$ \\
\hline
\end{tabular}

Table 3: Descriptive Statistics for the Following Factors on Importance When it Comes to Purchasing Tires.

\begin{tabular}{|c|c|c|c|c|c|c|c|c|c|c|c|}
\hline & \multicolumn{2}{|c|}{ Important } & \multicolumn{2}{|c|}{$\begin{array}{l}\text { Somewhat } \\
\text { Important }\end{array}$} & \multicolumn{2}{|c|}{ Neutral } & \multicolumn{2}{|c|}{$\begin{array}{c}\text { Somewhat } \\
\text { Unimportant }\end{array}$} & \multicolumn{2}{|c|}{$\begin{array}{c}\text { Not } \\
\text { Important }\end{array}$} & \multirow[b]{2}{*}{ Tota } \\
\hline & $\mathrm{F}$ & $\%$ & $\mathrm{~F}$ & $\%$ & $\mathrm{~F}$ & $\%$ & $\mathrm{~F}$ & $\%$ & $\mathrm{~F}$ & $\%$ & \\
\hline Price & 59 & $55 \%$ & 31 & $29 \%$ & 6 & $6 \%$ & 6 & $6 \%$ & 6 & $6 \%$ & 108 \\
\hline $\begin{array}{c}\text { Availability of } \\
\text { Tires }\end{array}$ & 18 & $18 \%$ & 33 & $34 \%$ & 29 & $30 \%$ & 11 & $11 \%$ & 7 & $7 \%$ & 98 \\
\hline $\begin{array}{l}\text { Customer } \\
\text { Service }\end{array}$ & 18 & $18 \%$ & 31 & $31 \%$ & 31 & $31 \%$ & 9 & $9 \%$ & 10 & $10 \%$ & 99 \\
\hline $\begin{array}{c}\text { Company } \\
\text { Purchased } \\
\text { From }\end{array}$ & 4 & $4 \%$ & 13 & $13 \%$ & 37 & $38 \%$ & 21 & $21 \%$ & 23 & $23 \%$ & 98 \\
\hline Tire Brand & 11 & $11 \%$ & 25 & $25 \%$ & 20 & $20 \%$ & 25 & $25 \%$ & 18 & $18 \%$ & 99 \\
\hline Distance & 20 & $20 \%$ & 29 & $29 \%$ & 29 & $29 \%$ & 7 & $7 \%$ & 14 & $14 \%$ & 99 \\
\hline
\end{tabular}




\section{Joshua Thomas Aarbo}

Table 4: Descriptive Statistics for Likeliness To Use These Online Features if Available When Purchasing Tires

\begin{tabular}{|c|c|c|c|c|c|c|c|c|c|c|c|}
\hline & \multicolumn{2}{|c|}{ Very Likely } & \multicolumn{2}{|c|}{ Likely } & \multicolumn{2}{|c|}{ Neutral } & \multicolumn{2}{|c|}{ Un-likely } & \multicolumn{2}{|c|}{ Very Un-likely } & \\
\hline & $\mathrm{F}$ & $\%$ & $\mathrm{~F}$ & $\%$ & $\mathrm{~F}$ & $\%$ & $\mathrm{~F}$ & $\%$ & $F$ & $\%$ & Total \\
\hline $\begin{array}{l}\text { Personal-ized } \\
\text { Sorting }\end{array}$ & 24 & $25.0 \%$ & 36 & $37.5 \%$ & 25 & $26.0 \%$ & 9 & $9.4 \%$ & 2 & $2.1 \%$ & 96 \\
\hline $\begin{array}{c}\text { Cell Phone } \\
\text { App }\end{array}$ & 16 & $15.5 \%$ & 20 & $19.4 \%$ & 24 & $23.3 \%$ & 21 & $20.4 \%$ & 17 & $16.5 \%$ & 98 \\
\hline Reminders & 21 & $20.4 \%$ & 42 & $40.8 \%$ & 17 & $16.5 \%$ & 7 & $6.8 \%$ & 11 & $10.7 \%$ & 98 \\
\hline $\begin{array}{c}\text { Online } \\
\text { Question }\end{array}$ & 11 & $10.7 \%$ & 35 & $34.0 \%$ & 21 & $20.4 \%$ & 22 & $21.4 \%$ & 9 & $8.7 \%$ & 98 \\
\hline FAQ & 20 & $19.4 \%$ & 40 & $38.8 \%$ & 24 & $23.3 \%$ & 8 & $7.8 \%$ & 4 & $3.9 \%$ & 96 \\
\hline Product Info & 36 & $35.0 \%$ & 46 & $44.7 \%$ & 10 & $9.7 \%$ & 4 & $3.9 \%$ & 4 & $3.9 \%$ & 100 \\
\hline Reviews & 47 & $45.6 \%$ & 36 & $35.0 \%$ & 8 & $7.8 \%$ & 2 & $1.9 \%$ & 4 & $3.9 \%$ & 97 \\
\hline
\end{tabular}




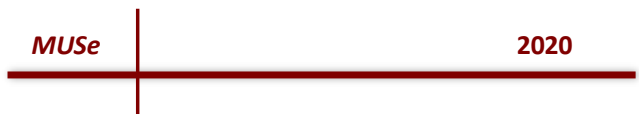

Table 5: Descriptive Statistics for Likeliness To Purchase Tires Online if the Features Selected Were Available.

\begin{tabular}{|l|c|c|}
\hline & Frequency & Percent \\
\hline Very Unlikely & 7 & $6.8 \%$ \\
\hline Unlikely & 15 & $14.6 \%$ \\
\hline Neutral & 28 & $27.2 \%$ \\
\hline Likely & 45 & $43.7 \%$ \\
\hline Very Likely & 8 & $7.8 \%$ \\
\hline Total & 103 & $100 \%$ \\
\hline
\end{tabular}

Analysis of Research Questions

Research Question \#1: Does the annual household income of respondents in our target market affect the likelihood that they will purchase tires online?

Our initial intention was to measure the respondent's age against their likelihood to purchase online. However, we were limited due to of a lack of responses outside the target market. Instead, we will be analyzing the correlation between annual household income and the likelihood to purchase tires online by conducting a bivariate analysis.

90 observations were used in this analysis. Tables 6 and 7 illustrate the findings of the analysis. Since the $p$-value of .253 is greater than 0.05 , we cannot reject Ho. Therefore, the correlation between these two variables is not significantly different from 0 . The correlation between "annual household income" and "how likely are you to purchase tires if the features you named were offered?" is observed to be 0.122 . In other words, annual household income does not have a significant impact on the likelihood that a respondent would purchase tires online. These findings disprove our hypothesis, which stated that we believe a high annual household income would increase the likeliness to shop for tires online. 
Table 6: Descriptive Statistics for Annual Household Income vs. Likeliness to Shop Online for Tires

\begin{tabular}{|l|l|l|l|}
\hline & Mean & Std. Deviation & N \\
\hline Annual Household Income & 2.7556 & 1.91570 & 90 \\
\hline $\begin{array}{l}\text { How likely are you to purchase tires if the } \\
\text { features you named were offered? }\end{array}$ & 3.3107 & 1.03875 & 103 \\
\hline
\end{tabular}

Table 7: Correlations for Annual Household Income vs. Likeness to Purchase Tires Online

\begin{tabular}{|c|c|c|c|}
\hline & & $\begin{array}{l}\text { Annual } \\
\text { Household } \\
\text { Income }\end{array}$ & $\begin{array}{c}\text { How likely are you to } \\
\text { purchase if the features } \\
\text { you named were } \\
\text { offered? }\end{array}$ \\
\hline \multirow{3}{*}{$\begin{array}{l}\text { Annual } \\
\text { Household } \\
\text { Income }\end{array}$} & $\begin{array}{l}\text { Pearson } \\
\text { Correlation }\end{array}$ & 1 & .122 \\
\hline & Sig. (2-tailed) & & .253 \\
\hline & $\mathrm{N}$ & 90 & 90 \\
\hline \multirow{3}{*}{$\begin{array}{l}\text { Likeliness to } \\
\text { Purchase Tires }\end{array}$} & $\begin{array}{l}\text { Pearson } \\
\text { Correlation }\end{array}$ & .122 & 1 \\
\hline & Sig. (2-tailed) & .253 & \\
\hline & $\mathrm{N}$ & 90 & 103 \\
\hline
\end{tabular}

Research Question \#2: What will be the most important factors to the consumer when online tire shopping?

Our second research question was to determine the key factors in which consumers would want to see when purchasing tires online. This question is a univariate analysis as it is merely determining different variables within the same category and determining which is the most important. How we posed the question in the survey required the respondents to determine the importance of each variable instead of comparing it to the other factors within the list. For example, the respondent would consider the importance of the price of tires, then would consider the distance to travel separately. This provided us with more unique information on each variable.

Table 8 helps determine what key factors are important to our respondents if they were to purchase tires online. The 
most important factors are Price, Availability of Tires, and Customer Service. Price received the most emphasis of importance, followed very closely (nearly identically) by Availability of Tires and Customer Service. The company they purchase from, the tire brand, and travel distance each received a variant range of responses but did indicate they were not nearly as important as the previous three, as the trend was focused on neutral to not important. We also wanted to see if there was a correlation between the likelihood to purchase tires online and any of the key factors listed above. The following table provides a clear idea if any of these factors are associated with online purchasing. We will use a level of 0.05 significance to determine the importance of each variable.

Table 8: Correlations for Likeness to Purchase Tires Online vs. Factors on Importance When it Comes to Purchasing Tires.

\begin{tabular}{|l|l|c|}
\hline \multicolumn{2}{|l|}{} & $\begin{array}{c}\text { How likely are you to } \\
\text { purchase if the features } \\
\text { you named were offered? }\end{array}$ \\
\hline $\begin{array}{l}\text { How likely are you to } \\
\text { purchase if the } \\
\text { features you named } \\
\text { were offered? }\end{array}$ & Pearson Correlation & 1 \\
\cline { 2 - 4 } & $\mathrm{N}$ & 103 \\
\hline \multirow{2}{*}{$\begin{array}{l}\text { Price of Tires } \\
\text { Availability of Tires }\end{array}$} & Pearson Correlation & .106 \\
\cline { 2 - 4 } & Sig. (2-tailed) & .290 \\
\cline { 2 - 4 } & Pearson Correlation & 102 \\
\cline { 2 - 4 } & Sig. (2-tailed) & -.116 \\
\cline { 2 - 4 } & N & .256 \\
\hline
\end{tabular}




\begin{tabular}{|c|c|c|}
\hline & & $\begin{array}{l}\text { How likely are you to } \\
\text { purchase if the features } \\
\text { you named were offered? }\end{array}$ \\
\hline \multirow[t]{3}{*}{ Customer Service } & Pearson Correlation & .103 \\
\hline & Sig. (2-tailed) & .308 \\
\hline & $\mathrm{N}$ & 99 \\
\hline \multirow{3}{*}{$\begin{array}{l}\text { Company Purchased } \\
\text { From }\end{array}$} & Pearson Correlation & -.103 \\
\hline & Sig. (2-tailed) & .313 \\
\hline & $\mathrm{N}$ & 98 \\
\hline \multirow[t]{3}{*}{ Tire Brand } & Pearson Correlation & -.034 \\
\hline & Sig. (2-tailed) & .736 \\
\hline & $\mathrm{N}$ & 99 \\
\hline \multirow[t]{3}{*}{ Travel Distance } & Pearson Correlation & .031 \\
\hline & Sig. (2-tailed) & .760 \\
\hline & $\mathrm{N}$ & 99 \\
\hline
\end{tabular}

The first variable to look at is the Price of Tires. It has a $p$-value of 0.290 , which is significantly higher than a value of 0.05 . Therefore, we cannot reject that the Price of Tires is not related to the likelihood to purchase tires online.

Next is the Availability of Tires. Similar to the Price of Tires, it received a $p$-value of 0.256 , which does not satisfy our level of significance, not accepting a correlation with purchasing tires online.

The rest of the variables show similar trends with no real association with the decision to purchase tires online. All of them have a p-value of 0.300 or higher, which will cause us to 


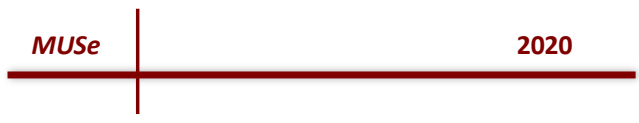

not reject the null hypothesis of no association of the factors of purchasing tires with the consumer's decision to purchase tires online.

This is key information to attain, as we have now determined that this will not ultimately change their decision to purchase tires online, however, we should be careful to notice which factors affect the respondents' purchasing decisions and alter the website so it is easy to access that proper information. Clear pricing, list of availability of tires, and an above standard customer service will help satisfy the customer's tire purchasing needs; it just won't add to their decision to purchase tires online.

Research Question \#3: Will having unique website features help encourage consumers to purchase tires online?

For this analysis, we tested the correlation between seven online features and the individual's likelihood to purchase tires online if the features were offered, as shown in Table 9 below. 
Table 9: Correlations for Likelihood to Purchase vs. Available Online Features

\begin{tabular}{|c|c|c|}
\hline & & $\begin{array}{c}\text { How likely are you to } \\
\text { purchase if the } \\
\text { features you named } \\
\text { were offered? }\end{array}$ \\
\hline \multirow{2}{*}{$\begin{array}{c}\text { How likely are you to purchase } \\
\text { if the features you named } \\
\text { were offered? }\end{array}$} & Pearson Correlation & 1 \\
\hline & $\mathrm{N}$ & 103 \\
\hline \multirow[t]{3}{*}{ Reviews } & Pearson Correlation & .247 \\
\hline & Sig. (2-tailed) & .015 \\
\hline & $\mathrm{N}$ & 97 \\
\hline \multirow[t]{3}{*}{ Product Info } & Pearson Correlation & .224 \\
\hline & Sig. (2-tailed) & .025 \\
\hline & $\mathrm{N}$ & 100 \\
\hline \multirow[t]{3}{*}{$\mathrm{FAQ}$} & Pearson Correlation & .142 \\
\hline & Sig. (2-tailed) & .169 \\
\hline & $\mathrm{N}$ & 96 \\
\hline \multirow[t]{3}{*}{ Online Question } & Pearson Correlation & .240 \\
\hline & Sig. (2-tailed) & .017 \\
\hline & $\mathrm{N}$ & 98 \\
\hline \multirow[t]{3}{*}{ Reminders } & Pearson Correlation & .214 \\
\hline & Sig. (2-tailed) & .034 \\
\hline & $\mathrm{N}$ & 98 \\
\hline
\end{tabular}




\begin{tabular}{|c|c|c|}
\hline \multicolumn{2}{|c|}{} & $\begin{array}{c}\text { How likely are you to } \\
\text { purchase if the } \\
\text { features you named } \\
\text { were offered? }\end{array}$ \\
\hline \multirow{2}{*}{ Personalized Sorting } & Pearson Correlation & .196 \\
\cline { 2 - 3 } & Sig. (2-tailed) & .056 \\
\cline { 2 - 4 } & N & 96 \\
\hline \multirow{2}{*}{ Cell Phone App } & Pearson Correlation & .201 \\
\cline { 2 - 4 } & Sig. (2-tailed) & .047 \\
\cline { 2 - 3 } & N & 98 \\
\hline
\end{tabular}

Below is a summary of the results for each feature from Table 9 .

Reviews: Because the $p$-value of 0.015 is less than 0.05 , we reject Ho. The correlation between these two variables is significantly different from 0 . The correlation between "Reviews" and "How likely are you to purchase if the features you named were offered?" is 0.247 .

Product Info: Because the p-value of 0.025 is less than 0.05 , we reject $\mathrm{Ho}$. The correlation between these two variables is significantly different from 0 . The correlation between "Product Info" and "How likely are you to purchase if the features you named were offered?" is 0.224 .

FAQ: Because the $p$-value of 0.169 is more than 0.05 , we cannot reject Ho. The correlation between these two variables is not significantly different from 0 . The correlation between "FAQ" and "How likely are you to purchase if the features you named were offered?" is 0.142 .

Online Question: Because the p-value of 0.017 is less than 0.05 , we reject $\mathrm{Ho}$. The correlation between these two variables is significantly different from 0 . The correlation 
between "Online Question" and "How likely are you to purchase if the features you named were offered?" is 0.240 .

Reminders: Because the $p$-value of 0.034 is less than 0.05 , we reject $\mathrm{Ho}$. The correlation between these two variables is significantly different from 0 . The correlation between "Reminders" and "How likely are you to purchase if the features you named were offered?" is 0.214 .

Personalized Sorting: Because the $p$-value of 0.056 is more than 0.05 , we cannot reject $\mathrm{Ho}$. The correlation between these two variables is not significantly different from 0 . The correlation between "Personalized Sorting" and "How likely are you to purchase if the features you named were offered?" is 0.196 .

Cell Phone App: Because the p-value of 0.047 is less than 0.05 , we reject $\mathrm{Ho}$. The correlation between these two variables is significantly different from 0 . The correlation between "Cell Phone" and "How likely are you to purchase if the features you named were offered?" is 0.201 .

Based on these observations, it can be determined that the online features that have the most significant impact on the consumer's likelihood to purchase tires online are reviews, product information, online question service, and reminders. However, the correlation of many of these variables is not incredibly high, ranging from $14.2 \%-24.7 \%$. Because of this, we can say that, if a company was wanting to implement a number of online features, the best options for them to start out with are reviews, product information, and an online question service, while it is beneficial to ignore developing an app, personalized sorting, or an FAQ.

Research Question \#4: Will education influence which factors are the most important when purchasing tires?

Our fourth research question was to determine whether education would influence which factors are the most important when purchasing tires. The table for this analysis is shown below (Table 10). In the survey, respondents were 
required to determine the importance of each individual variable as opposed to a comparison between the variables. For example, the respondent would consider the importance of the customer service, then would consider the tire brand, all as separate variables with no relation to the other. This was beneficial as it provided stand-alone information for each variable. 
Table 10: Correlations for Education vs. Factors on Importance When it Comes to Purchasing Tires.

\begin{tabular}{|c|c|c|}
\hline & & Level of Education \\
\hline \multirow[t]{3}{*}{ Price of Tires } & Pearson Correlation & .005 \\
\hline & Sig. (2-tailed) & .964 \\
\hline & $\mathrm{N}$ & 102 \\
\hline \multirow[t]{3}{*}{ Availability of Tires } & Pearson Correlation & -.031 \\
\hline & Sig. (2-tailed) & .764 \\
\hline & $\mathrm{N}$ & 98 \\
\hline \multirow[t]{3}{*}{ Customer Service } & Pearson Correlation & -.016 \\
\hline & Sig. (2-tailed) & .875 \\
\hline & $\mathrm{N}$ & 99 \\
\hline \multirow{3}{*}{$\begin{array}{c}\text { Company Purchased } \\
\text { From }\end{array}$} & Pearson Correlation & .052 \\
\hline & Sig. (2-tailed) & .614 \\
\hline & $\mathrm{N}$ & 98 \\
\hline \multirow[t]{3}{*}{ Tire Brand } & Pearson Correlation & .163 \\
\hline & Sig. (2-tailed) & .107 \\
\hline & $\mathrm{N}$ & 99 \\
\hline \multirow[t]{3}{*}{ Travel Distance } & Pearson Correlation & .105 \\
\hline & Sig. (2-tailed) & .300 \\
\hline & $\mathrm{N}$ & 99 \\
\hline
\end{tabular}




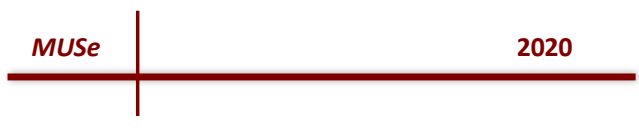

With regards to education, our consensus was that the less educated an individual, the less importance they would place on brand and company and the more importance they would place on price. In contrast, we expected that higher educated individuals would place more importance on availability of tires and travel distance than those who are less educated would. Despite our hypotheses, this was not the case. In order to accept our hypothesis, the $p$-value (Sig.) of each variable, would have to be less than 0.05 . As you can deduce from the above table, this is not the case. In fact, there is no significance between these variables and education at all, thus, we do not accept our hypothesis that education will influence which factors are the most important when purchasing tires.

Research Question \#5: Is there a correlation between the likelihood respondents would shop online and how likely respondents would purchase tires online?

103 observations were used in this analysis, as shown in the tables below (Tables 11 and 12). Since the p-value of .002 is lower than 0.05 , we reject Ho. Therefore, the correlation between these two variables is significantly different from 0 . The correlation between "likelihood to shop online" and "likelihood to purchase tires online" is observed to be 0.30 . Therefore, we can see that the likelihood to shop online is significantly correlated with the likelihood to purchase tires online. These findings prove our hypothesis that the two variables are correlated and influence one another.

Table 11: Descriptive Statistics for the Correlation of Shopping Online and Purchasing Tires Online

\begin{tabular}{|l|c|c|c|}
\hline & Mean & Std. Deviation & $\mathrm{N}$ \\
\hline Likelihood that you would shop online & 3.7087 & 1.08131 & 103 \\
\hline $\begin{array}{l}\text { How likely are you to purchase if the } \\
\text { features you named were offered? }\end{array}$ & 3.3107 & 1.03875 & 103 \\
\hline
\end{tabular}


Table 12: Correlations of Shopping Online and Purchasing Tires Online

\begin{tabular}{|c|c|c|c|}
\hline & & $\begin{array}{l}\text { Likelihood } \\
\text { that you } \\
\text { would shop } \\
\text { online }\end{array}$ & $\begin{array}{c}\text { How likely are you to } \\
\text { purchase if the features } \\
\text { you named were } \\
\text { offered? }\end{array}$ \\
\hline \multirow{3}{*}{$\begin{array}{l}\text { Likelihood that } \\
\text { you would } \\
\text { shop online }\end{array}$} & $\begin{array}{l}\text { Pearson } \\
\text { Correlation }\end{array}$ & 1 & $.300^{* *}$ \\
\hline & Sig. (2-tailed) & & .002 \\
\hline & $\mathrm{N}$ & 103 & 103 \\
\hline \multirow{3}{*}{$\begin{array}{l}\text { How likely are } \\
\text { you to } \\
\text { purchase if the } \\
\text { features you } \\
\text { named were } \\
\text { offered? }\end{array}$} & $\begin{array}{l}\text { Pearson } \\
\text { Correlation }\end{array}$ & $.300^{* *}$ & 1 \\
\hline & Sig. (2-tailed) & .002 & \\
\hline & $\mathrm{N}$ & 103 & 103 \\
\hline
\end{tabular}

\section{Conclusion and Recommendations}

The research we have completed has given us a new outlook on the adaptability and viability of tire sales within an online market after developing the question of "how can tires be sold on an ecommerce platform successfully" by utilizing different resources. We started with a thorough literature review of scholarly articles to gain knowledge on the issue we were about to undertake. After, we conducted five in-depth interviews within the target market of consumers aged 20 to 30 to develop common themes which would be prevalent to a successful online tire shopping experience. We then developed a survey, related to the themes we derived from the interviews, from which we received 103 responses within the target market. After putting the information into SPSS, we determined key factors on which to place emphasis into our five research questions that would help us best understand the market. 


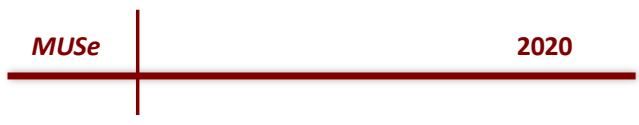

To successfully implement an ecommerce platform within the target market of consumers aged 20 to 30 , it should be acknowledged many of these people have either not bought tires previously or have only done so once. This means that many of the consumers may not know exactly what they are looking for. To successfully implement an ecommerce platform, the website must accommodate this and provide very clear and easy to access information. The pricing of tires, the availability of the tires, and customer service similar to an in-store purchase were key factors the target market wants to see and would make it easier and more comfortable for them to complete such a purchase online. This should be implemented in a few different ways. Based on the results of our research, reviews of tires, and an online question service, which allows the customer to ask questions to a representative, are factors that were positively received. Having the product information easily shown and described will also help the customer make informative purchases, easing their purchasing decision.

We further recommend focussing on current users of online shopping, as such a purchase may be harder to justify for people who have never shopped online before. It should be emphasized that the customer service should be similar to the service that they would receive in one of your stores. It allows them to feel comfortable making a large purchase. This can be done with our recommendations of an online question service with a representative, and reviews of each tire from previous purchasers or customers.

Finally, we recommend further research into an older target market. While we did not receive many responses from this demographic, it showed some positive results that a slightly older demographic may be inclined to purchase tires online. Our belief behind this is due to the markets experience with tire purchases. Since they have most likely purchased tires more than once, they will have a clearer idea as to which tires 
they want, therefore, making a large purchase online easier than the target market of 20 to 30 that we have researched.

If these recommendations are followed it is possible to successfully create an ecommerce platform for online tire sales, which will provide an engaging, well informed and safe purchasing environment for customers.

\section{Limitations}

During the data collection we have faced a few limitations that should be noted. The first is that most of our information gathered was within the target age range of 20 to 30 . While it does not pose a threat to the whole process, it does not help provide data for reference purposes. Gathering more data outside the target age range may have helped determine different factors regarding online tire purchasing. Another limitation we had was that all our data was collected via an online survey. This means that the data given to us may not be $100 \%$ accurate, as we do not necessarily know if the respondent was truthful. An example of this is that they lie about how much money they are making to avoid unpleasant feelings. In an ideal setting we would have gathered more survey responses to develop more accurate data collection, however, due to time constraints, only so many responses could be obtained. 


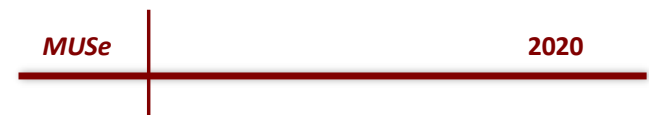

\section{References}

Akar, E., \& Nasir, V. A. (2015). A review of literature on consumers' online purchase intentions. Journal of Customer Behaviour. 14(3), 215-233. Retrieved from http://www.ebscohost.com

Bhatnagar A. \& Syam, S. (2013). Allocating a hybrid retailer's assortment across retail stores: Bricks-and-mortar vs online. Journal of Business Reasearch. 67 (2014), 1293-1302. Retrieved from http://web.a.ebscohost.com

Bialystok Technical University. (2010). Customers' experiences as a factor affecting perceived service quality. Economics and Management. 2010(15), 820-826.

Bretthauer, K., Mahar S. \& Venakataramanan M.A. (2009). Computers \& Industrial Engineering. Computers \& Industrial Engineering. 58 (2010) 119-132. Retrieved from http://web.a.ebscohost.com.

Bulearca, M., Bulearca, S. (2009). Internet and interactive websites: cornerstones of competitive advantage in the virtual economy: Global Business \& Management Research. 1(3/4), 44-56. Retrieved from http://web.a.ebscohost.com

Chin, C., \& Swatman, P. (2005) The Virtual Shopping Experience: Using virtual presence to motivate online shopping. Australasian Journal of Information Systems. 13(1), 239-253, DOI: http://dx.doi.org/10.3127/ajis.v13i1.74

Chong, W., Bian, D., \& Zhang, N. (2016) E-marketing services and e-marketing performance: the roles of innovation, knowledge complexity and environmental turbulence in influencing the relationship. Journal of Marketing Management. 32(2), 149-178, DOI: 10.1080/0267257X.2015.1102758.

Cui, N., Wang, T., \& Xu, S. (2010) The Influence of Social Presence on Consumers' Perceptions of the Interactivity of Web Sites. Journal of Interactive 
Advertising. 11(1), 36-49. Retrieved from http://web.a.ebscohost.com.

D’Avanzo, E. \& Kuflik, T. (2013). E-Commerce websites services verses buyers expectations: An empirical analysis of the online marketplace. International Journal of Information Technology \& Decision Making. 12(4), 651-677. DOI: 10.1142/S0219622013500247.

Deneen, K., Yu, D. (2015). Online shopping is making many customers antagonistic: Gallup Business Journal. 4. Retrieved from http://web.a.ebscohost.com

Falk, L., Sockel, H. \& Chen, K. (2005). E-Commerce and consumer's expectations: what makes a website work. Journal of Website Promotion. 1(1), 65-75. Retrieved from http://content.ebscohost.com

Gallino, S. \& Moreno, A. (2014). Integration of Online and Offline Channels in Retail: The Impact of Sharing Reliable Inventory Availability Information. Management Science. 60(6):1434-1451. Retrieved from http://web.a.ebscohost.com

Hon Tshin, E. Y., Tanakinjal, G. H., \& Sondoh Jr., S. L. (2014). The Key Dimensions of Online Service Quality: A Study of Consumer Perceptions. IUP Journal Of Marketing Management. 13(2), 7-18. Retrieved from http://www.ebscohost.com

Jing X., Lewis, M. (2011). Stockouts in Online Retailing. American Marketing Association . Journal of Marketing Research. Vol. XLVIII (April 2011), 342-354. Retrieved from http://web.a.ebscohost.com.

Karimi, S., Papamichail, K. N., \& Holland, C. P. (2015). The effect of prior knowledge and decision-making style on the online purchase decision-making process: A typology of consumer shopping behaviour. Decision Support Systems. 77, 137-147. Retrieved from http://www.ebscohost.com

Li, Z., Lu Q., \& Talebian M. (2015). Online versus bricksandmortar retailing: a comparison of price, assortment 


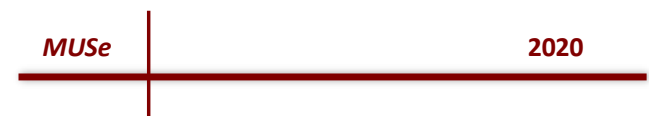

and delivery time. International Journal of Production Research, 53:13, 3823-3835, DOI: 10.1080/00207543.2014.973074.

Michalowska, M., Kotylak, S., Danielak, W. (2015) Forming relationships on the e-commerce market as a basis to build loyalty and create value for the customer. 19(1), 57-72. Retrieved from http://web.a.ebscohost.com.

Nai-Hua, C. \& Ya-Wen, H. (2015). Online shopping orientation and purchase behaviour for high-touch products. International Journal Of Electronic Commerce Studies. 6(2), 187-201. Retrieved from http://www.ebscohost.com

Nord, J.H., Paliszkiewicz, J., Koohang, A. (2014). Using social technologies for competitive advantage: impact on organizations and higher education: Journal of Computer Information Systems. 55(1), 92-104. Retrieved from http://web.a.ebscohost.com

Pappas, N. (2015). Marketing strategies, perceived risks, and consumer trust in online buying behaviour. Journal of Retailing and Consumer Services. 29 (2016), 92-103. Retrieved from http://www.ebscohost.com Pilinkiene, V., Kurschus, R.J., Auskalnyte, G. (2013). E-Business as a source of competitive advantage: Journal of Computer Information Systems. 55(1), 92-104. Retrieved from http://web.a.ebscohost.com Singh, A. \& Khanduja, D. (2014). Defining quality management in auto sector: A six-sigma perception. Procedia Materials Science. 5(2014). 2645-2653. Retrieved from http://resolver.Irc.macewan.ca

Sikora, J. (2014). In store vs. online. Retail Merchandiser. 54(6), 8-9. Retrieved from http://web.a.ebscohost.com Talpau, A., Bratucu, G., \& Vierasu, T. (2013) Top Romanian Brands Online Presence - Behavior and success strategies. 2, 13-23. Retrieved from http://web.a.ebscohost.com. 
Yieh, K., Chiao, Y. \& Chiu, Y. (2007). Understanding the Antecedents to Customer Loyalty by Applying Structural Equation Modeling. Total Quaility Management \& Business Excellence. 18(3), 267-284. Retrieved from http://content.ebscohost.com 


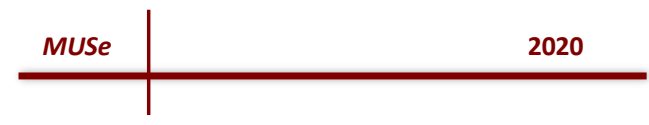

Appendices

Appendix A: Questionnaire

Online Tire Purchase Questionnaire

This is a research project for the Marketing Research 312

course at MacEwan University. The purpose of this

questionnaire is to analyze consumer's attitudes towards online shopping, and to identify any barriers that may exist when purchasing a tire online. The results from this questionnaire will be used to develop recommendations for Tireland regarding their interest in implementing e-commerce into their sales and marketing plan. This questionnaire contains ten questions and should take approximately ten minutes to complete. Your participation is voluntary and you have the right to withdraw at any point without consequence. Any and all information obtained from our research will be kept confidential and anonymous.

Any questions or concerns can be directed to Dr. Fernando Angulo at Fernando.AnguloRuiz@macewan.ca.

1. How frequently do you shop online?

$\square$ Never

$\square$ Rarely

$\square$ Sometimes

$\square$ Often

$\square$ Always

2. What is the likelihood that you would shop online?
$\square$ Very Unlikely
Unlikely
$\square$ Neutral
Likely
$\square$ Very Likely

3. How often do you find your information before making an online purchase from these sources?

(1-Never, 2-Rarely, 3-Sometimes, 4-Often, 5 - Always)
( ) Online Research
( ) Reviews
( ) Speaking to an Expert ( ) Asking a Friend
Don't Do Research 
4. Which of these companies are you familiar with? Select all that apply.
( ) OK Tire
( ) Tirecraft
( ) Kal Tire
( ) Fountain Tire
( ) Canadian Tire
( ) TireLand

5. Have you ever purchased tires for your vehicle?
$\square$ Yes
$\square$ No

6. If you selected "yes", where have you purchased tires from? Select all that apply.
( ) OK Tire
( ) Tirecraft
( ) Kal Tire
( ) Fountain Tire
( ) Canadian Tire
( ) TireLand
( ) Other
( ) Not Applicable

7. Please rate the following factors on importance when it comes to purchasing tires. Least Important (1) to Most Important (6).

Price of Tires

Customer Service Brand Availability of Tires Company Purchased From $\overline{\text { Tire }}$ Travel Distance

8. What is the likelihood that you would use these online features if available when purchasing tires?

(1 - Very Unlikely, 2 - Unlikely, 3 - Neutral, 4 - Likely, 5 - Very Likely)
( ) Reviews
( ) Availability of Information
( ) FAQ
( ) Online Chat Service
( ) Reminders (Pick Up Ready/Tire Change Due)
( ) Sorting Tool to Compare/Contrast Best Tires for You
( ) Cell Phone App 


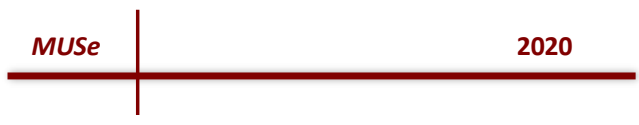

9. If a tire company's website offered the features you selected in question 8 , how likely would you be to purchase tires online?
$\square$ Very Unlikely
$\square$ Unlikely
$\square$ Neutral
Likely
$\square$ Very Likely

10. What obstacles would prevent you from purchasing tires online?

\section{FOR CLASSIFICATION PURPOSES ONLY}

Gender
$\square$ Male
$\square$ Female
$\square$ Other

Age
$\square 19$ or Under
$\square$ 20-30
$\square$ 31-40
$\square$ 41-50
$\square$ 51-60
$\square 61+$

Income
$\square 20,000$ or Less
$\square 20,001-40,000$
$\square$ 40,001-60,000
$\square$ 60,001-80,000
$\square 80,001-100,000$
$\square 100,000+$

\section{Education}
$\square$ High School
$\square$ Diploma
$\square$ Degree
Masters
$\square$ PHD
$\square$ Other

Hours Worked (Per Week)
$\square$ None
$\square$ 5-10
$10-20$
$\square$ 20-30
$\square$ 30-40
$\square$ 40+

Thank you for your participation. 


\section{Appendix B: Discussion Guide}

Introduction and Explanation

- Who we are: A group of MacEwan students conducting research for Tireland following guidelines by Marking Research (MARK 312).

- What our purpose is: To gain information needed to assist Tireland in making a decision regarding the problem facing them.

- Purpose of the interview: The purpose of this interview is to gain further insight into what consumers would need to consider purchasing tires online.

- Research Problem: To determine how to make Tireland's target market more interested in buying tires online and how this, along with current practices, can lead to and ensure continued success.

- Explanation and signing of consent form.

Demographics:

\begin{tabular}{|l|l|}
\hline Individual Interviewed & \\
\hline Age & \\
\hline Occupation & \\
\hline Interviewer & \\
\hline Date & \\
\hline
\end{tabular}

1. What have your online shopping experiences and history been like? Were they positive or negative experiences and why?

2. Do you use online information tools (reviews, in stock, etc.) to make purchase decisions?

3. If you've ever purchased tires or other automotive parts, where did you get the information? 
4. How often have you bought new or used tires? Did the brand or store matter?

5 . What factors are important to you when purchasing tires (rate from 1-6, 1 being the most important and 6 being the least important):

6. How far would you be willing to travel to acquire a specific set of tires?

7. What aspects/characteristics would you like to see in a website you purchase tires from?

8. What would you need to motivate you to purchase tires online rather than going to the store?

9. Would you prefer finding information for a tire purchase online and then buying it in person, or to have the whole purchase online and why?

10. Would you be open to purchasing tires online? If not, what are the obstacles preventing you?

11. Would you like an interactive experience when purchasing tires online or a simple basic experience? 